\title{
Introduction: Children's Cultures and Media Cultures
}

\author{
Cristina Ponte ${ }^{1}$ \\ Cesnova/FCSH, Universidade Nova de Lisboa, Portugal \\ Piermarco Aroldi \\ OssCom - Università Cattolica del Sacro Cuore, Milan, Italy
}

\section{doi:10.5937/comman1329007P}

In the ever changing landscape of (old and new) media and their audiences, convergence between children's cultures and media cultures is an increasingly topical field of study. To name but some of the challenges this reality presents, one could note how children and adolescents are continually exposed to the expansion of global digital TV channels addressed to them; how the growing investment in marketing activities is often associated with new forms of publicity and participation in new platforms like SNSs or mobile communication; how new social practices born of changing family structures and the fast paced rhythm of everyday life make children's lives not only far more institutionalised, but also increasingly individualistic. In fact, today children's lives are influenced by a culture that is dominated by personal and mobile media far more than it ever was in past generations (Livingstone, 2009; Lemish, 2013).

Over the last 15 years, media regulators and producers have contributed to establishing a set of normative frameworks and co-regulation systems that protect children from being negatively affected by inappropriate content or contacts (von Feilitzen and Carlsson, 2003; Lunt and Livingstone, 2012). Public and private institutions have stimulated content providers to raise the quality of their media production and programmes for children and to ensure that young users can only access suitable content, as parent associations and child advocacy

\footnotetext{
1 cristina.ponte@fcsh.unl.pt
} 
groups have often raised these issues. At the same time, and particularly in Western societies, the fact that all citizens have access to digital technologies is a huge concern. In Europe this concern has led to recommendations and deliberations from both the European Commission and the European Parliament, and some countries' governments have even created specific technological plans for education (Selwyn, 2003).

The wide diffusion of digital devices in everyday life, as well as the convergence of media brands and characters addressed to kids and teens in terms of a cross-platform perspective make children a very particular audience that is becoming more and more accustomed to engaging with preferred contents through a wide range of channels, technologies, formats and rituals. For the most part, media contents and platforms have entered into the realm of childhood as games or recreational tools, making it hard to distinguish between them. On the one hand, videogames and consoles have colonised everyday life spaces and times and often incorporate both mobile and domestic screens, while on the other hand toys and games frequently refer to narratives or involve characters originating in media blockbusters. Notwithstanding the widespread reach of mobile connectivity and out-of-home communication, family still remains a social environment affected by children's media practices and interpretations. At the same time, structural change in the household and in families in general, along with cultural changes, is reconfiguring the values and strategies of parental mediation (Lemish, 2007).

Furthermore, children negotiate meanings and values in their peer groups, developing constellations of tastes and preferences, thus producing their own cultures. Here again there is a dichotomy: media contents enter into peer groups and contribute to shaping their taste cultures, while peer group belonging influences children's orientation toward their media taste and consumption habits. Convergence between media cultures and consumer cultures is visible in processes like merchandising, where an interwoven combination of media texts and promotional gadgets contextualises a range of commodities under one coherent concept, or product placement, a strategy that involves the positioning of a branded product within a desirable media context in order to strengthen its image (Jansson, 2001). This kind of convergence is very common in children's media and raises many questions regarding consumption, exploitation and socialisation (Ekström and Tufte, 2007; Buckingham, 2011). 
For all the above mentioned reasons, the connection between children's cultures and media cultures can be considered a privileged area of innovation, in which many different actors and stakeholders (children, parents, educators, producers, marketing agents, regulators, policy makers and, last but not least, scholars) constantly negotiate the meaning of childhood in our globalised societies. In relation to this point, we would like to highlight how research into children's and digital media is also an area of methodological innovation, as has been shown by two recent publications from the EU Kids Online network, both available online. The report How to research children and online technologies? Frequently asked questions and best practice, (Livingstone, Ólafsson and Haddon, 2013) reviews and updates a previous edition launched in 2008, while the report Innovative approaches for investigating how children understand risk in new media. Dealing with methodological and ethical challenges (Barbovschi, Green and Vandoninck, 2013) places emphasis on the sensitive question of what constitutes online risk and how to research it with children.

In the following pages, some of the aforementioned topics are studied in greater depth and debated on different levels, starting with children's experience of everyday life and arriving at the concepts put forward by public policies and institutions. The articles in this special issue are predominantly characterised by an international dimension. Some of them focus on the dialectic between local contexts and the processes of globalisation, sometimes in comparative terms, while others look at cross-national products, such as TV programs or SNSs. The methodology adopted in these studies is heterogeneous, combining quantitative and qualitative analyses. In addition to textual analyses of media documents, audience research tools such as surveys, face to face interviews and focus groups with children appear alongside the virtual ethnography that is delineated through young media users' interventions on the websites they frequent. The role played by cultural contexts in differentiating children's media experience emerges in all of these articles, as does the relevance of age, gender and reflexivity in the shaping of children's agency and participation.

As a consequence of the ongoing globalisation of both media and societies, media contents for children are also being marketed on an ever-expanding international scale, and new generations are more likely to become "citizens of the globe”. Ebba Sundin discusses the findings from a complex, interview-based study focused on children, media and local cultural identity in teenagers grow- 
ing up in extremely unusual and complex cultural, national and geographical locations - such as the Faroe and Aland islands -, and from a textual analysis of cultural expressions published by Canadian children's reporters in a daily newspaper. Empirical examples, combined with a theoretical framework of the media's role in defining aspects of both global and local realities and contributing to the individual's sense of belonging, allow for a better understanding of how children and adolescents make sense of media, as well as determining what output media might have when it comes to young media users' shaping of images through existing cultural identities.

If children are social actors, just as adults are, to what extent do media cultures allow for, or mean to, their agency and participation? In the wake of the "media savvy" or "digital native" generations, what kind of children's audiences are scholars looking at? What models of "active publics" are producers developing in children's media? How is media participation constructed in young individuals' practices? Some answers can be found in the article proposed by Sirkku Kotilainen and Annikka Suoninen, which presents the results of the Comparative Research on Youth Media Participation project. Based on the survey results of this project, which involved 4300 respondents from four countries (Argentina, Egypt, Finland and India) the article highlights different perspectives on audiencehoods in media-related discussions focused on media participation. Indeed, interest in societal issues and participation through the media as parts of children's cultural activities seems to depend more on needs and motivation than on technical devices. The authors also highlight the relevance of media criticism, ethical reflections and skills for creative public expression as forms of media and information literacy that support participatory media activities.

Recent research into the links between children and mobile technologies - for example, the results that emerged from the European project Net Children Go Mobile - restated the relevance of gender in identifying differences in children's varying experience of digital media. While the boyhood culture is strongly oriented toward online gaming and seems to be lived in more private conditions, the girlhood culture tends to be oriented towards more public communication practices (Mascheroni and Ólafsson, 2013). It may not be a coincidence that none of the articles in this edition addresses the more closed world of boys' relation to the media, while two articles address this gender-specific 
topic from a perspective that is focused on how girls' live out their relationship with media and the relevant observations that can be drawn from this practice.

Indeed, the convergence between media cultures and consumer cultures affects young girls in a very particular way, and this is particularly evident in the media approach to young girls by several fashion brands. Fashion and media cultures draw on and intertwine elements of socialisation in order to contribute to the shaping of personal identity and the acquisition of social roles, as well as in order to define what is to be accepted as "normal" or otherwise. Gender and age roles, moral values, lifestyles and behaviours are reproduced, confirmed and contested in the symbolic space of cultural productions, especially when they are addressed to a young female target (Mazzarella, 2013).

In order to investigate how online activities and digital cultures mediate girls' socialisation with consumer culture, Mari Mäkiranta analyses the TOPModel magazine as an example of a cultural phenomenon which closely links identity construction to consumerism. TOPModel and its virtual chat forums provide a space in which girls can play, form social relations and use their creative potential, but this figures as a complex negotiation, rather than as stable features that define the self, girls' bodily representations, consuming habits or social relations. Having followed Finnish children's messages and interaction in a chat forum for months, the author explores the world of the TOPModel brand, asking what kinds of creativity its online forums stimulates in girls, and focusing on the meanings and practices that the girls themselves attribute to their actions. The analysis reveals a kind of engagement that can be defined as a sense of formability and belonging: Even in a ready-made and highly regulated platform that emphasises consumerism, girls reformulate the predefined online topics, creating alternative designs and forming social relationships. TOPModel magazines can thus be understood as sites that celebrate girlhood and creativity while questioning the bond between social class, gender and consumerism.

In a similar framework, but this time using a face-to-face focus group methodology with girls aged 9-13, Francesca Pasquali and Giovanna Mascheroni discuss the findings of a research project involving Italian users of Stardoll.com, an online dress-up game for tweens that focuses on fashion. Located within a nexus of commercialised practices that operate in both online and offline worlds, often in continuity with Barbie dress up play, this paper doll website is analysed as a toolkit for managing identities and experimenting with patterns 
of adult femininity. Stimulating reflexivity on identity performances, gender stereotypes and the role of fashion and celebrities, this kind of gaming practice provides girls with a space in which they can experiment and make sense of their engagement with consumer culture and its norms. This kind of website can thus be seen as a "virtual bedroom" in which girls socialise and relate with celebrity culture, normative gender patterns and codes of dressing-up.

Where globalisation and commercialisation meet, Disney is probably there. Therefore, it is not surprising that two articles coming from countries as distant as Argentina and Israel deal with the same global media conglomerates, their representations of children and the tendency to reproduce Disney's cultural models in original cross media and online platforms.

In Carolina Duek's article, the description and characterisation of the hegemonic representation of children presented by major global media (with Disney in the lead) is compared with an analysis of what Argentinean children said about media and play in their everyday lives. The analysis of global media contents evidences children's representation as autonomous subjects who know what they want, and the role of hyper-pedagogisation in the domestic environment assumed by the "friendly" media of television (e.g. educational content, suggestions of politically correct social behaviour and tips about personal hygiene). Interviews involving an Argentinean sample of boys and girls aged between six and ten show that television is identified as a member of the family that is "taken for granted". In fact, the space of desires, expectations and struggles are now more frequently related to new technologies and especially to Facebook as a social network where games and sociability are strategically combined. As the author comments, "the struggles that children narrated when trying to convince parents to open their Facebook accounts are clearly articulated by the representations of children that major global television companies pursue twenty four hours a day".

In contrast, while analysing Mikmak, a popular multi-channel Israeli platform that targets children aged 5 to 12 and is made up of several spaces (a computer game, a blog, a television series, an off-line commercialised play-ground and, finally, on- and off-line stores), David Levin and Sharon Ramer-Biel show that complex socialisation processes exist in all of the platform's convergent elements. On the basis of a content analysis of the site and upon observation and conversations with children in three different areas (during the virtual play, in 
the commercialized off-line play-ground and during recess in the school yard) the authors distinguish three levels of interaction - between players and their off-line friends, between players and their parents and between players and the changing values in Israeli society during the late capitalist era. Through these different levels, a sort of "Disneyzation" process (Bryman, 1999) works to create a "closed text" and addresses a target audience of children as individual consumers.

Focusing on an institutional point of view, the last two articles analyse how children are viewed in public education policies and digital divide concepts, and how they are represented in the news media.

In their paper, Lana Ciboci, Igor Kanižaj and Danijel Labaš analyse public complaints regarding the violation of children's rights in Croatian news media over the last five years. The first part of the study analyses legal rulings that have judged the media guilty of violating children's rights regulations and examines complaints accusing members of the Croatian Journalists' Association of violating the association's Code of Honour. This section also looks at reports issued by the Office of the Ombudsman for children in response to complaints involving violations of children's rights in the media. The second part of the paper presents a case study, through which qualitative and quantitative content analyses allow the authors to demonstrate how both print and electronic media violate legal and ethical norms that protect children's rights. By questioning the efficiency of self-regulation and proposing new initiatives for co-regulation, the authors offer guidelines for the protection of children's rights in the media, while offering new insight for the institutions responsible for supervising the implementation of the relevant regulations and ethical norms.

The last article, authored by Sara Pereira, describes Portugal's Technological Plan for Education, namely the e.escolinha programme (2008-2011), which was a public policy that targeted primary school children and was similar to the One Laptop per Child project. Pereira analyses a number of documents produced by public offices at the moment of the programme's launch and a sample of interviews with policy makers. These discourses revealed a distinctly reductive definition of the age group involved, in as much as all children seem to be considered as having the same needs, the same interests and the same lifestyle. While no mention is made of what children know in their present times, great attention is dedicated to the competencies that children are expected to acquire 
before coming to adulthood. This kind of approach affects both the representation of technology and of children: the child is seen as a citizen in the making, while the computer is ascribed the role of a tool that helps children face their distant future. The article also includes children's comments on the subject, which were collected in a survey that asked questions about their personal and school experiences and what they think about the end of the programme. This two-sided analysis helped reveal the political interests and economic concerns that shape this kind of educational programmes in the digital age, as well as how these policies tend to ignore the role of children as social actors.

As a final note, this special issue of CM emerged from the European COST Action IS0906, Transforming Audiences, Transforming Societies (2010-2014). Within its Working Group on Audience Transformations and Social Integration, the interrelation between children and media environments in both the public arena and in terms of experiences linked to private uses has become a lively point of discussion. As editors, we are extremely grateful to CM for having instigated and facilitated the organisation of a special issue on this topic and, of course, to the authors who have contributed to its content. 


\section{References}

Barbovschi, M., Green, L. \& Vandoninck, S. (eds.) (2013). Innovative Approaches for Investigating How Children Understand Risk in New Media. Dealing with Methodological and Ethical Challenges. London: EU Kids Online, London School of Economics and Political Science. Accessed 20.9.2013. URL: http://www.lse.ac.uk/media@lse/research/EUKidsOnline/EU\%20 Kids\%20III/Reports/InnovativeMethods.pdf.

Bryman, A. (1999). The Disneyization of Society. The Sociological Review, 47(1), 25-47.

Buckingham, D. (2011). The Material Child: Growing up in Consumer Culture. Cambridge: Polity Press.

Ekström, K.M. \& Tufte, B. (eds.) (2007). Children, Media and Consumption. On the Front Edge. Göteborg: The International Clearinghouse on Children, Youth and Media, Göteborg University.

Jansson, A. (2001). Image Culture. Media, Consumption and Everyday Life in Reflexive Modernity. Göteborg: JMG Göteborg University.

Lemish, D. (2007). Children and Television. Oxford: Blackwell.

Lemish, D. (ed.) (2013). The Routledge International Handbook of Children, Adolescents and Media. Abingdon: Routledge.

Livingstone, S. (2009). Children and the Internet. Cambridge: Polity Press.

Livingstone, S., Ólafsson, K. \& Haddon, L. (2013) How to Research Children and Online Technologies? Frequently Asked Questions and Best Practice. EU Kids Online, EU Kids Online Network, London. Accessed 20.9.2013. URL: UK. http://eprints.lse.ac.uk/50437/.

Lunt, P. \& Livingstone, S. (2012). Media Regulation: Governance and the Interests of Citizens and Consumers. London: Sage Publications Ltd. 
Mascheroni, G. \& Ólafsson, K. (2013) Net Children Go Mobile. Mobile Internet Access and Use among European Children. Initial findings of the Net Children Go Mobile Project. Milano: Educatt.

Mazzarella, S.R. (2013). Media and Gender Identities: Learning and Performing Feminity and Masculinity. In Lemish, D. (ed.), The Routledge International Handbook of Children, Adolescents and Media. Abingdon: Routledge, pp. 279-286.

Selwyn. N. (2003). Doing IT for the Kids: Re-examining Children, Computers and the Information Society. Media Culture and Society, 25(3), 351-378.

Von Feilitzen, C. \& Carlsson, U. (eds.) (2003). Promote or Protect? Perspectives on Media Literacy and Media Regulations. Göteborg: The International Clearinghouse on Children, Youth and Media, Göteborg University. 